\title{
POTENSI DAN PERMASALAHAN DRAINASE DI KELURAHAN ARJOSARI, KEC. BLIMBING, KOTA MALANG
}

\author{
Bambang Joko Wiji Utomo \\ Dosen Prodi Arsitektur, Fak. Teknik Sipil dan Perencanaan, ITN Malang \\ e-mail: bambangutomo92@gmail.com \\ Daim Triwahyono \\ Dosen Prodi Arsitektur, Fak. Teknik Sipil dan Perencanaan, ITN Malang \\ e-mail: daimtri@gmail.com \\ Soeranto Darsopuspito \\ Dosen Prodi Arsitektur, Fak. Teknik Sipil dan Perencanaan, ITN Malang \\ e-mail: soerantods@gmail.com
}

\begin{abstract}
ABSTRAK
Sejak tahun 2009 di setiap kelurahan di kota Malang mendapatkan dana bantuan dari pemerintah kota malang yang berupa dana hibah kepada masyarakat kelurahan melalui LPMK sebesar Rp. 500.000.000,- per tahun, dengan tujuan untuk pemberdayaan masyarakat kelurahan, serta untuk pembangunan fisik kelurahan yang belum tersentuh oleh pembangunan timgkat kota. Dengan adanya bantuan dana yang cukup besar untuk kelurah dan harus dipertanggungjawabkan secara profesional maka LPMK dan kelurahan harus dapat mengalokasikan dana tersebut secara tepat sasaran dan benar-benar bermanfaat untuk pembangunan masyarakat kelurahan. Untuk hal tersebut kelurahan membutuhkan data kondisi masyarakat yang benar-benar akurat dan dapat di pertanggungjawabkan, baik data kondisi sosial ekonomi masyarakat maupun sarana prasarana yang di butuhkan oleh masyarakat. sehingga di butuhkan pendataan ulang kondisi sosial ekonomi maupun sarana dan prasarana kelurahan yang lebih valid dan realible. sehingga dapat di manfaatkan sebagai pedoman dalam penyusunan program pembangunan kelurahan baik yang di biayai oleh dana hibah kepada masyarakat maupun yang didanai oleh dana $A P B D$ pemerintah kota Malang.
\end{abstract}

Kata kunci : Potensi dan permasalahan Drainase, kelurahan Arjosari

\section{ABSTRACT}

Since 2009, in each Village in Malang City have received assistance from the Malang city government in the form of grants to the Village community through LPMK of Rp. 500,000,000 per year, with the aim of empowering urban villages, as well as for the physical development of urban villages that have not been touched by the construction of urban centers. With the existence of substantial 
funding assistance for Villages and professional accountability, the $\angle P M K$ and the Village must be able to allocate these funds in a targeted manner and truly be beneficial for the development of the Village community. For this matter, the Village needs data on community conditions that are truly accurate and accountable, both the data on the socio-economic conditions of the community and the infrastructure needed by the community, so that a re-socioeconomic condition and more valid urban facilities and infrastructure are needed and reliable, so that it can be utilized as a guideline in the development of urban development programs both financed by grants to the community as well as those funded by the Malang city government budget funds.

\section{Keywords : Design, Plot, Public Facilities.}

\section{PENDAHULUAN}

Selama ini banyak program-program pemerintah yang bertujuan untuk mengentaskan kemiskinan baik dari pemerintah pusat, propinsi maupun kabupaten/kota.. Bahkan karena banyaknya program justru kesannya berjalan sendiri-sendiri atau tidak ada sinergi antar program yang ada, padahal tujuannya sama-sama untuk masyarakat dalam penanggulangan kemiskinan. Hasil dari program-program penanggulangan kemiskinan yang sudah dilaksanakan sampai sekarang pun belum membuahkan hasil yang mengembirakan. Masyarakat yang hidup di bawah garis kemiskinan masih banyak dan bahkan cenderung meningkat jumlahnya.

Program - program tersebut baik dalam proses perencanaan maupun pelaksanaan .langsung ditangani oleh masyarakat kelurahan, yang pada dasarnya awam terhadap perencanaan maupun pelaksanaan pembangunan, sehingga yang terjadi adalah pembangunan yang bersifat sektoral dan invidual, karena disebabkan banyaknya kepentingan pribadi pengurus-pengurus lembaga kemasyarakatan kelurahan, serta kurang pahamnya masyarakat terhadap tujuan dan proses pembangunan.

Demikian juga yang terjadi pada Kelurahan Arjosari Kecamatan Blimbing Kota Malang, yang belum memiliki buku pedoman pembangunan yang berupa rencana pembangunan kelurahan baik yang berupa rencana pembangunan jangka panjang, maupun jangka menengah, sehingga pembangunan yang terjadi adalah pembangunan yang bersifat sektoral dan sporadis.

Dengan adanya kondisi yang demikian maka dibutuhkan adanya perencanaan pembangunan di tingkat kelurahan yang sifatnya terpadu antara perencanaan dari atas (topdown) dan perencanaan dari bawah (Bottomup) sebagai aspirasi masyarakat kelurahan.

PAWON: Jurnal Arsitektur, Nomor 02 Volume III, Juli-Desember 2019, ISSN 2597-7636 
Guna menunjang perencanaan pembangunan kelurahan yang optimal maka perlu adanya data yang cukup guna mendukung proses perencanaan, sehingga urgensitas pemetaan permasalahan dan potensi masyarakat kelurahan menjadi penting.

\section{TINJAUAN PUSTAKA}

Dari beberapa permasalahan yang ada, apabila diidentifikasikan terdapat tiga masalah utama yaitu :

1. Belum adanya pedoman yang dapat digunakan sebagai sumber dalam membuat perencanaan pembangunan di tingkat Kelurahan, sehingga kegiatan yang dilakukan dalam menangani maupun menanggulaangi permasalahan masih bersifat responsif, yaitu menyelesaikan permasalahan yang ada tanpa melihat pengaruhnya terhadap dampak lanjutannya.

2. Penyelesaian permasalahan lingkungan, ekonomi dan sosial cenderung sektoral, sehingga tidak ada keterpaduan dan tidak menyeluruh.

3. Permasalahan drainase lingkungan yang kurang lancer membuang limpasan air hujan.

Oleh karena itu, maka berdasarkan hasil musyawarah dengan perangkat lembaga Kelurahan baik lembaga pemerintahan maupun non pemerintahan ditemukan suatu kesepemahan yaitu perlunya adanya dokumen yang menggaambarkan potensi maupun permasalahan yang ada di Kelurahan Arjosari sehingga dapat dijadikan sumber data baik dalam menentukan arah pembangunan maupun sumber dalam menentukan skala prioritas penyelesaian permasalahan baik dari aspek lingkungan, ekonomi dan sosial. Adapun solusi yang ditawarkan dengan:

a. Metode Pendakatan Pemacahan Masalah

1. Kerjasama antara lembaga perguruan tinggi dengan lembaga Kelurahan Arjosari, dalam bentuk Pengabdian pada Masyarakat

2. Melibatkan masyarakat dalam proser pendataan dan perencanaan pembangunan Kelurahan.

3. Menyusun Rencana Pembangunan Kelurahan yang terpadu yang berbasis pada komunitas.

b. Rencana Kegiatan Upaya Pemecahan Masalah

1. Melakukan persiapan dan koordinasi Tim untuk melaksanakan kegiatan pemetaan permasalahan kelurahan Arjosari. 
2. Bersama perangkat kelurahan, melasanakan Sosialisasi kegiatan kepada masyarakat kelurahan

3. Melibatkan masyarakat dalam proser pendataan

4. Pembagian tugas keseluruh TIM, baik nerdasarka wilayah maupun berdasar pada materi.

5. Menyusun dan mengorganisir data untuk disajikan secara sistematis, sesuai dengan kepentingan perencanaan pembangunan kelurahan.

6. Bersama perangkat kelurahan, melasanakan Sosialisasi hasil kegiatan kepada masyarakat kelurahan

c. Partisipasi Masyarakat Kelurahan

Partisipasi masyarakat diharapkan dalam proses pendataan, terutama para perangkat RT dan RW, sebagai penunjuk dan sumber informasi permasalahan diwilayahnya masing-masing.

\section{METODE PENELITIAN}

Proses pendataan dilakukan dengan cara dibagi dalam 5 (lima) wilayah pendataan sesuai dengan wilayah ke RW an pada lokasi. masingmasing wilayan akan dilakukan oleh 2 orang survaiyor, yang di bantu oleh perangkat RW dan satu tenaga dari kelurahan dengan alokasi waktu survai selama 6 hari kalender. Dengan metoda survai sebagai berikut :

1. Langkah pertama adalah melakukan pengumpulan data sekunder yang di miliki oleh kelurahan.

2. Langkah kedua dilakukan pengumpulan data primer di lapangan yang di dahului dengan

3. Sosialisasi di setiap di setiap wilayah survai (sesuai dengan pembagian wilayah/5 wilayah $\mathrm{RW}$ ) yang di dampingi oleh seorang perangkat kelurahan.

4. Langkah berikutnya pengisian quisener oleh perangkat masing2 $\mathrm{RW}$, yang dilanjutkan dengan peninjauan lapangan, mencocokan antara data sekunder dengan data primer dilapangan.

5. Mendiskripsikan kondisi apa yang ada di lapangan.

6. Menyusun data termutakhir secara sistematis agar mudah di baca dan di mengeti oleh masyarakat setempat. 


\section{HASIL DAN PEMBAHASAN}

Berdasarkan UURI No. 4/1992 (tentang Perumahan dan Permukiman) dapat diketahui berbagai jenis prasarana permukiman seperti yang tercantum dalam Pasal 5 - 7, meliputi:

a. Sarana dasar yang utama bagi berfungsinya suatu lingkungan permukiman adalah (Pasal 5):

1. Jaringan jalan untuk mobilitas manusia dan angkutan barang, pencegahan perambatan kebakaran, serta untuk menciptakan ruang dan bangunan yang teratur;

2. Jaringan saluran pembuangan air limbah dan tempat pembuangan sampah untuk kesehatan lingkungan; dan

3. Jaringan saluran air hujan untuk pengatusan/drainase, dan pencegahan banjir setempat.

Dalam keadaan tidak terdapat air tanah sebagai sumber air bersih, jaringan air bersih merupakan sarana dasar.

b. Fasilitas penunjang dimaksud dapat meliputi aspek ekonomi yang antara lain berupa bangunan perniagaan/perbelanjaan yang tidak mencemari lingkungan. Sedangkan fasilitas penunjang yang meliputi aspek sosialbudaya, antara lain berupa bangunan pelayanan umum dan pemerintahan, pendidikan dan kesehatan, peribadatan, rekreasi dan olah raga, pemakaman dan pertamanan (Pasal 6).

c. Utilitas umum meliputi antara lain: jaringan air bersih, jaringan listrik, jaringan telefon, jaringan gas, jaringan transportasi, dan pemadam kebakaran. Fasilitas umum membutuhkan pengelolaan secara berkelanjutan dan profesional oleh badan usaha agar dapat memberikan pelayanan yang memadai kepada masyarakat (Pasal 7). Namun terbalik dengan aturan yang tercantum pada UURI No. 4/1992 (tentang Perumahan dan Permukiman) dengan kenyataan yang ada di lapangan bahwa tidak semua pemukiman penduduk memiliki saluran pembuangan air kotor/drainase terutama didaerah warga perkampungan sedangkan pada perumahan yang ada di kelurahan Arjosari rata-rata sudah memiliki drainase yang cukup memadai.

\section{KESIMPULAN}

Permasalahan Drainase/ limpasan air hujan

Adanya beberapa drainase yang mengalami pendangkalan, sehingga mengakibatkan bila terjadi hujan saluran air hujan tidak lancar akibat selanjutnya adalah terjadinya genangan air hujan sesaat, bila terjadi hujan yang deras akan terjadi banjir. 
Pemanfaatan sungai yang ada belum maksimal, artinya pembuangan air hujan belum semuanya terbuang ke sungai yaitu kali mewek dan kali kidul (saluran irigasi)

Sedangkan potensi yang ada adalah adanya dua sungai yang melelui kelurahan arjosari sehingga pembuangan air hujan bisa melalui sungai yaitu "kali kidul" dan "kali mewek" serta "sungai bangau" yang cukup besar.

Adannya sungai sangat bermanfaat sekali untuk pembuangan limpasan air hujan bagi kelurahan arjosari.

\section{DAFTAR PUSTAKA}

Direktorat Jenderal Perhubungan Darat. 1998. Pedoman Perencanaan dan Pengoperasian Fasilitas Parkir. Jakarta: Direktorat Bina Sistem Lalulintas dan Angkutan Kota.

Direktorat Jenderal Perhubungan Darat. 1996. Pedoman Teknis Penyelenggaraan Fasilitas Parkir. Jakarta.

Hobbs, FD. 2004. Perencanaan Teknik Lalu Lintas. Edisi Kedua. Yogyakarta: Gadjah Mada University Press.

Mc. Shane, W.R and Roess, R.P. 1990. Traffic Engineering. New Jersey: Prentice Hall.

Pemerintah Kota Surabaya. 1996. Pedoman Perencanaan dan Bangunan Fisik Bidang Tata Ruang Wilayah Kotamadya Surabaya Tahun 1996. Surabaya. 